\title{
31. BIOSTRATIGRAPHIC SUMMARY OF DSDP LEG 44: WESTERN NORTH ATLANTIC OCEAN
}

\author{
Felix M. Gradstein, ${ }^{1}$ David Bukry, ${ }^{2}$ Daniel Habib ${ }^{3}$ Otto Renz, ${ }^{4}$ \\ Peter H. Roth, ${ }^{5}$ Ronald R. Schmidt, ${ }^{6}$ Fred M. Weaver, ${ }^{7}$ and Frank H. Wind ${ }^{8}$
}

\section{INTRODUCTION}

During Leg 44 of the Deep Sea Drilling Project five sites (388-392) comprising 11 holes were drilled in the western North Atlantic Ocean off the east coast of the United States. Water depth at the sites ranges from about 2600 to 5000 meters. A total of 1342.5 meters was cored of which 546.8 meters were recovered $(41 \%)$ in 149 cores. Sediments range from Upper Jurassic through Quaternary although no Cenomanian-Santonian, upper Eocene-(?) Oligocene, and Pliocene sediments were found.

Most of the cores recovered were studied both for calcareous nannoplankton (R. Schmidt) and foraminifers (F.M. Gradstein). Tertiary sediments were analyzed for radiolarians ( $\mathrm{F}$. Weaver). In addition to these investigations by the three shipboard micropaleontologists, biostratigraphic contributions were received on Cenozoic nannofossils, silicoflagellates and diatoms (D. Bukry), Lower Cretaceous pollen and spores (D. Habib), Lower Cretaceous aptychi (O. Renz), Cretaceous nannofossils (P.H. Roth), and Upper Jurassic nannofossils of the Jurassic/Cretaceous boundary (F.H. Wind), and Cretaceous ostracodes (F. Swain). Bukry also reports on nine samples from Site 394 drilled near Site 391 during Leg 44A, an engineering trial to test the readiness of Glomar Challenger for the International Phase of Ocean Drilling (IPOD). In addition, 38 Cretaceous-Cenozoic samples from Site 390 and 392 were processed for palynomorphs (G. Williams), but the results were very disappointing. Diatoms are meager to abundant in the Blake-Bahama Basin Miocene of Cores 3 to 19 from Hole 391A and Cores 5 and 6 from Hole 394A. Diatoms are common in the Blake Nose Eocene of Cores 2 to 7 from Hole 390A. Both sequences are briefly described in conjunction with silicoflagellate studies. The stratigraphic distribution and relative abundance of microfossil groups from the Leg 44 and 44A sites are given schematically in Figure 1.

\section{Site 388 - Lower Continental Rise Hills}

Hole 388A, slightly northeast of Site 105 (DSDP Leg 11) on the lower continental rise hills, penetrated 341 meters of

\footnotetext{
${ }^{1}$ Geological Survey of Canada, Dartmouth, Nova Scotia, Canada.

${ }^{2}$ United States Geological Survey, La Jolla, California.

${ }^{3}$ Department of Earth and Environmental Sciences, Queens College, New York, New York.

${ }^{4}$ Museum of Natural History, Basel Switzerland.

${ }^{5}$ Department of Geology and Geophysics, University of Utah, Salt Lake City, Utah.

${ }^{6}$ Geological Institute, University of Utrecht, Utrecht, the Netherlands.

${ }^{7}$ Exxon Production Research, Houston, Texas.

${ }^{8}$ Department of Geology, Florida State University, Tallahassee, Florida.
}

Quaternary nannofossil-foraminifer clay with sand and silt layers, and upper and middle Miocene hemipelagic clay.

Quaternary planktonic foraminifers and nannofossils are abundant and well preserved. Benthic foraminifers in the Quaternary sediments may be partly reworked from the continental shelf or slope, and commonly occurring Miocene and Eocene radiolarians were probably winnowed from submarine outcrops along the continental slope.

Generally, only thick-shelled species of Miocene planktonic foraminifers are preserved; the tests are greatly fragmented and etched. The Miocene discoaster/coccolith ratio is very high and etching is common. The microfossil assemblages reflect their deposition in proximity to the calcium carbonate compensation depth (CCD).

Miocene planktonic foraminifers indicate zones of N.14-17 (middle and upper Miocene) in general agreement with the nannofossil zonation (NN 9?, NN 10, NN 11). Poorly preserved radiolarians in Hole 388A, Core 9, suggest the sediments are middle Miocene.

In Hole 388A, Core 5 (upper Miocene) microfossils between 60 and $150 \mu \mathrm{m}$ in size resembling Paleozoic acritarchs are common to abundant.

\section{Sites 389, 390, and 392 - Blake Nose}

Site 389 represents an abortive attempt to "spud in" on the Blake Nose, in a water depth of about 2720 meters. The one core recovered consists of sand, shells, and manganese nodules. Both nannofossils (Zones NN 20-21) and foraminifers (Zone N.23) indicate upper Quaternary sediments.

The nearby Blake Nose Sites 390 (206 m T.D.) and 392 ( $349 \mathrm{~m}$ T.D.) at a water depth of about 2650 meters together give a more or less continuously cored and remarkable fossiliferous succession of Cretaceous and lower Tertiary strata (see Figures 2, 3, and 4). Microfossil preservation is excellent throughout the section.

Cores 31 through 4 in Hole 392A and Cores 10 through 6 in Hole 390 are shallow-marine limestones. No other microfossils were recovered than non-age diagnostic foraminifers (mainly miliolids) and astracodes (Core 8) representing a mixture of more open marine and near-shore toxa. An exception is the uppermost limestone where well preserved and diversified foraminifer and nannofossil assemblages indicate Barremian sediment. In Sample 390-5, CC, chalky limestones are dated Barremian, on the basis of nannofossils ( $M$. hoschulzii Zone) and lower Aptian on the basis of foraminifers ( $G$. blowi Zone). Overlying sediments at both sites consist of upper Aptian through middle or upper Albian nannofossil oozes, unconformably overlain by upper Campanian oozes and followed upward by lower Maestrichtian through middle Eocene pelagic sediments. 
F.M. GRADSTEIN ET AL.

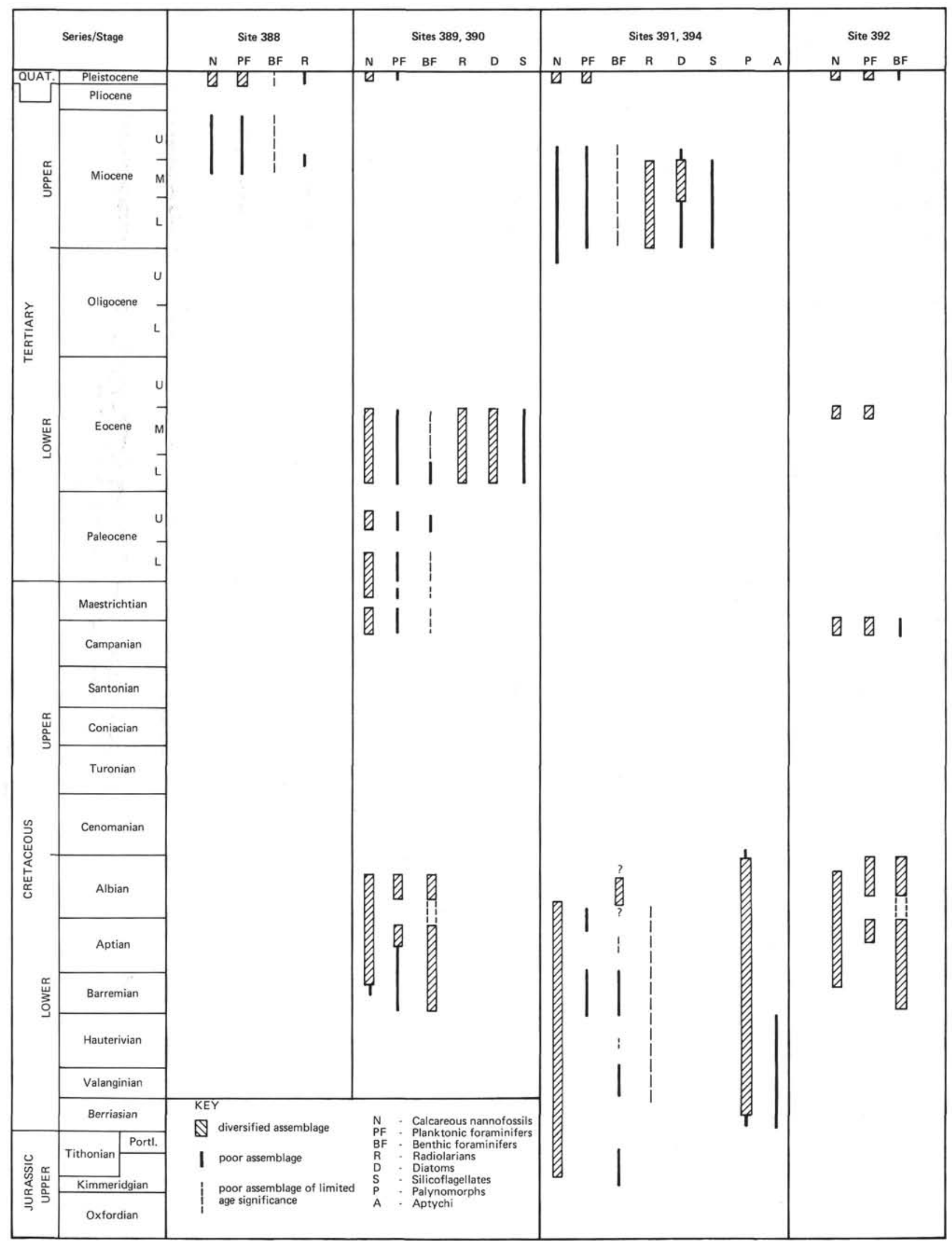

Figure 1. Stratigraphic distribution of microfossil groups at Sites 388-392, Leg 44 and Site 394, Leg 44A. 


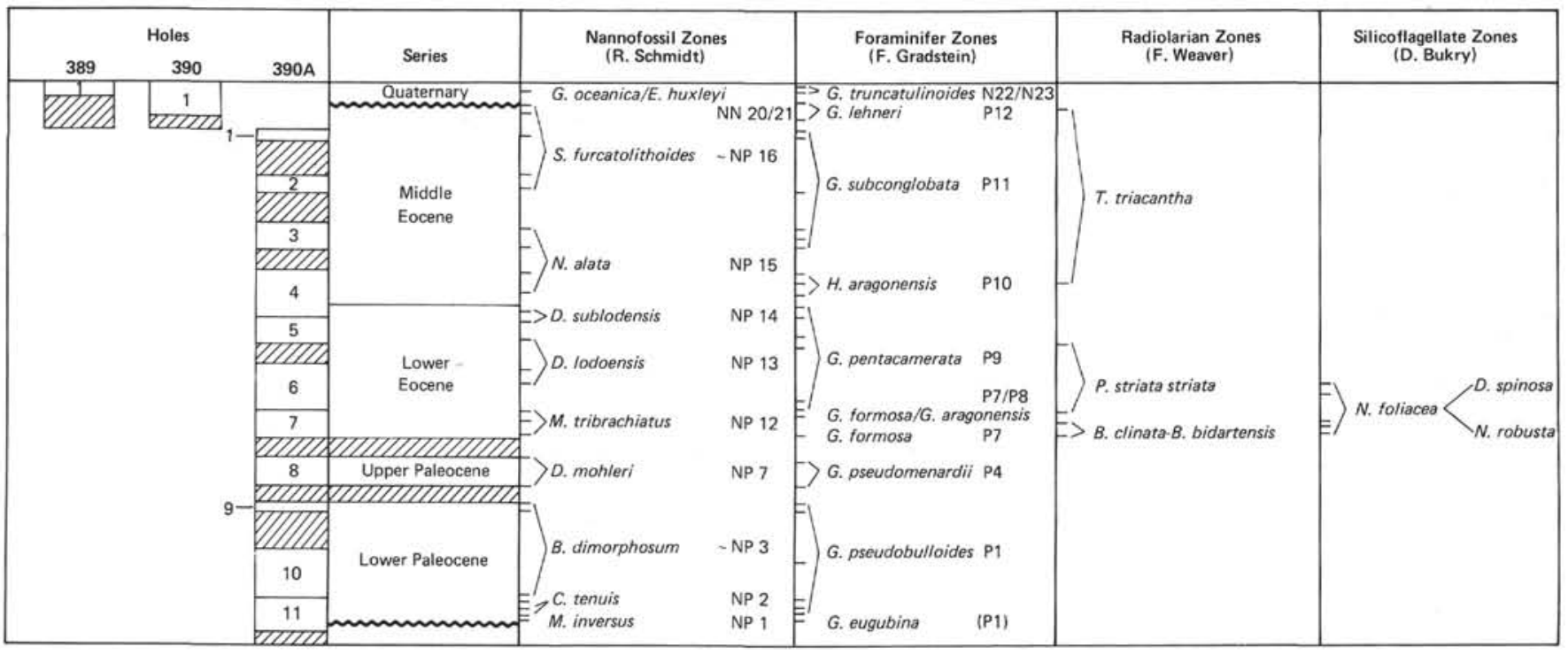

Figure 2. Biostratigraphy of the Cenozoic pelagic sediments at Sites 389 and 390, Blake Nose. Nannofossil zones are as determined by R. Schmidt; D. Bukry uses a different zonation but age designations are similar.

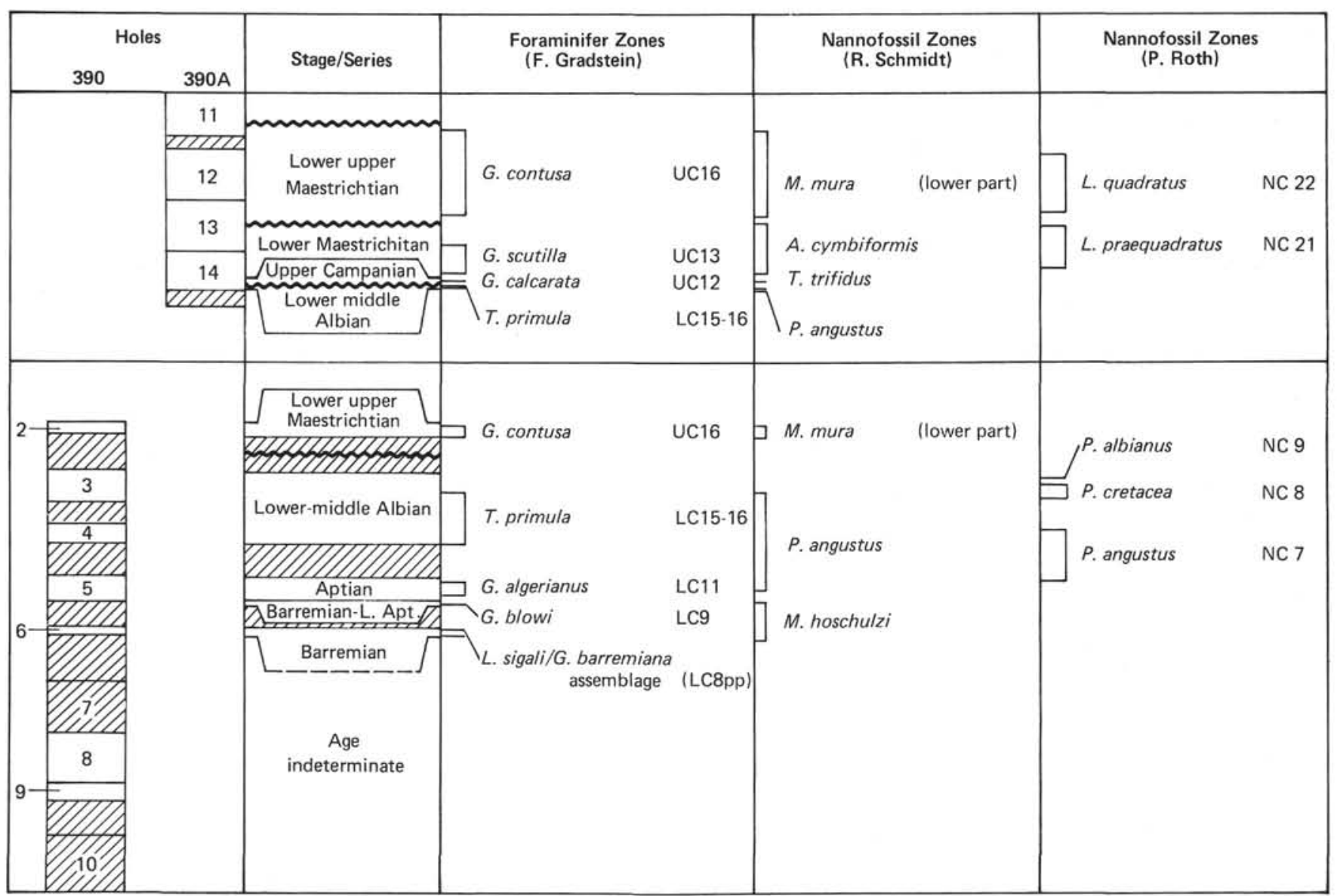

Figure 3. Biostratigraphy of the Cretaceous pelagic sediments at Site 390, Blake Nose. Cores 6-10 are from shallow marine limestone.

Lower Albian planktonic foraminifer zones (LC 12-14) which should be present in Hole 392A, Core 3 and uppermost Maestrichtian zones (upper part of $M$. mura nannofossil zone and $G$. mayaroensis foraminifer zone) which should be present in Hole 390A, Core 11 are apparently missing, suggesting possible hiatuses in these cores.

Sites 390 and 392 offer an excellent opportunity for a comparison of Barremian-Albian planktonic and benthic 


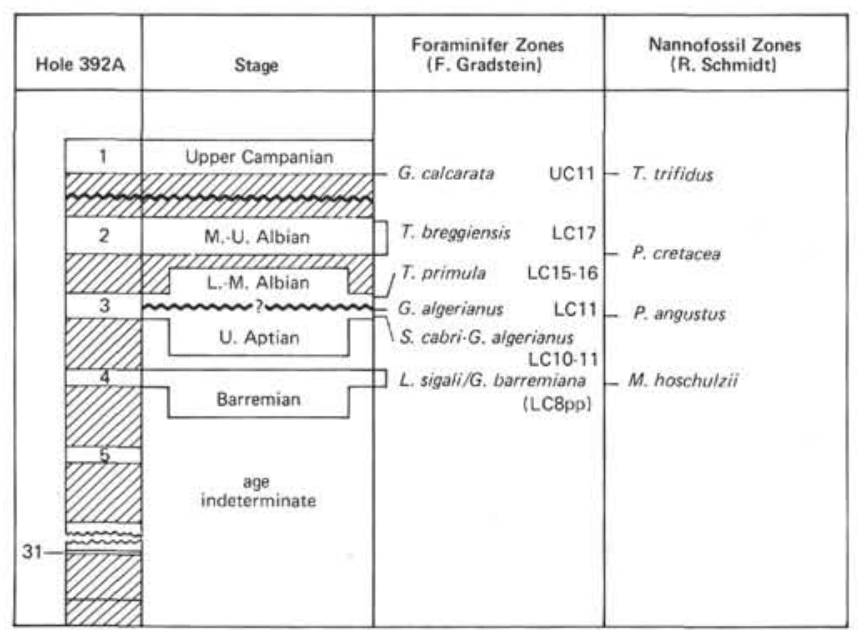

Figure 4. Biostratigraphy of the Cretaceous pelagic sediments from Hole 392A, Blake Nose. Cores 4-31 are from shallow marine limestone.

foraminifer and nannofossil zones and the very fossiliferous Eocene beds allow calibration of the radiolarian and silicoflagellate zones to the detailed calcareous microfossil zonation.

\section{Site 391 - Blake-Bahama Basin}

Site 391 , comprising four holes, was drilled in the Blake-Bahama Basin at a water depth of 4874 meters.

Hole 391A penetrated 659 meters of Quaternary and lower through upper Miocene sediments dated on the basis of nannofossils, foraminifers, and radiolarians. The site is remarkable for the thick succession of Miocene debris-flow carbonates interbedded with hemipelagic-pelagic (siliceous) mudstones which contain well-preserved radiolarian assemblages. Because of reworked sediments the strata are difficult to date, but the drilled section to a large extent comprises successively younger allochthonous Miocene assemblages which give minimum ages for deposits (Figure 5).

Reworked Cretaceous and Eocene microfossils are common in several debris-flow beds. Both shallow marine and deeper marine microfossils are found; for example, Eocene larger foraminifers are abundant in Core 12, and a large number of Eocene planktonic foraminifers found in Cores 4 and 5 .

Hole $391 \mathrm{C}$ penetrated to a sub-bottom depth of 1412 meters; 54 cores were recovered which extensively sampled uppermost Jurassic through Lower Cretaceous limestones and shales. The uppermost dark claystone in Core 4 just below lower Miocene chalk, lacks fossils that could provide an age assignment.

Relatively rich and well-preserved nannofossil and palynomorph assemblages indicate the presence of Tithonian and Berriasian to Albian strata which may be subdivided to the stage level. Additional stratigraphic information comes from sparse ostracode, foraminifer, and aptychi assemblages which make Hole $391 \mathrm{C}$ well suited for a multiple (Upper Jurassic) Lower Cretaceous biostratigraphy of deep marine deposits. However, as can be seen from Figure 6 , different age interpretations made on the basis of different fossil groups and/or by different workers may differ up to one stage apart. This stresses the need for further studies and comparisons of the Hole 391C microsfossils which may also focus on calpionellids, such as those observed in thin sections of Core 24. 


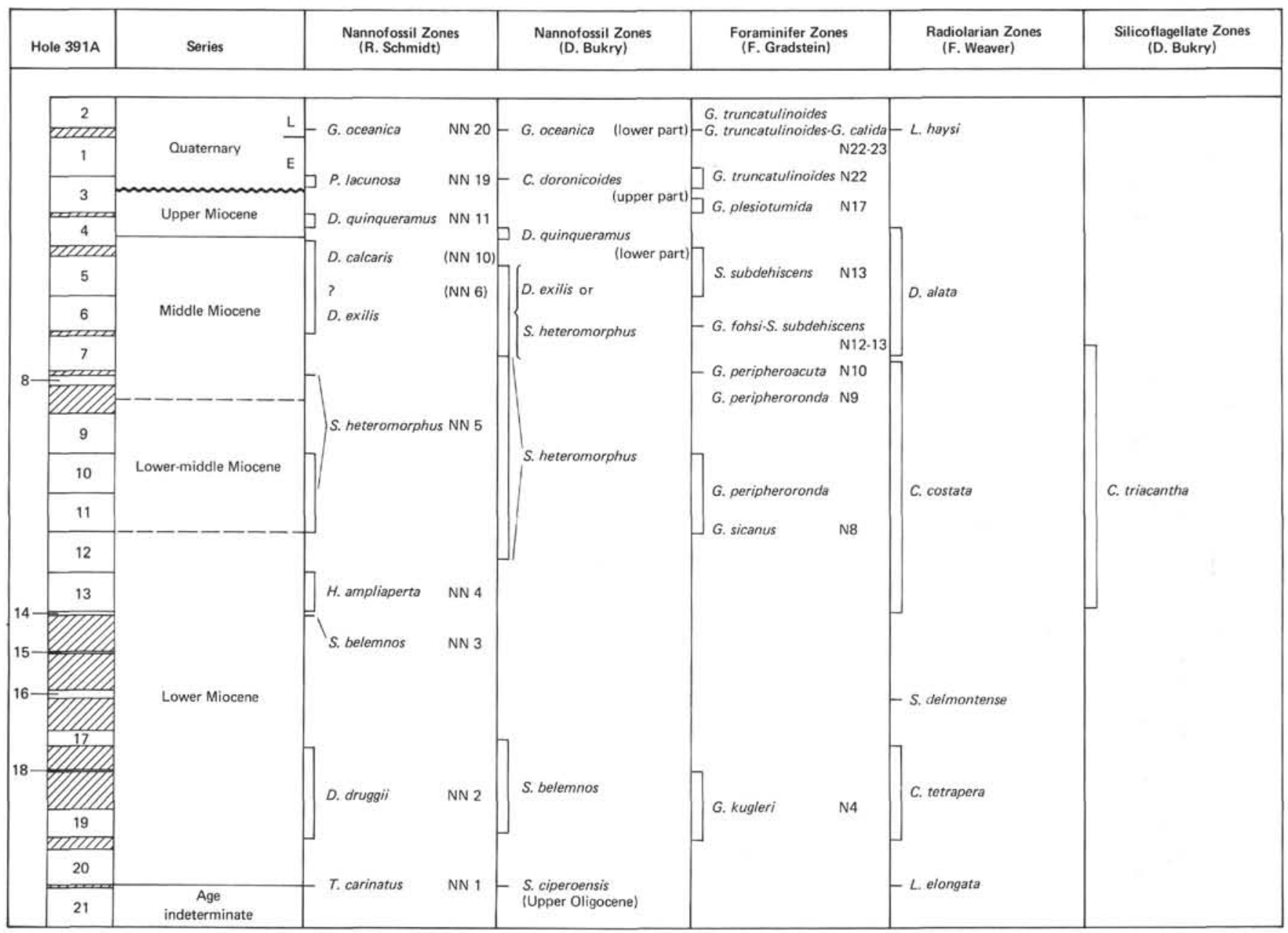

Figure 5. Biostratigraphy of the upper Cenozoic hemipelagic sediments from Hole 391A, Blake-Bahama Basin. 
F.M. GRADSTEIN ET AL.

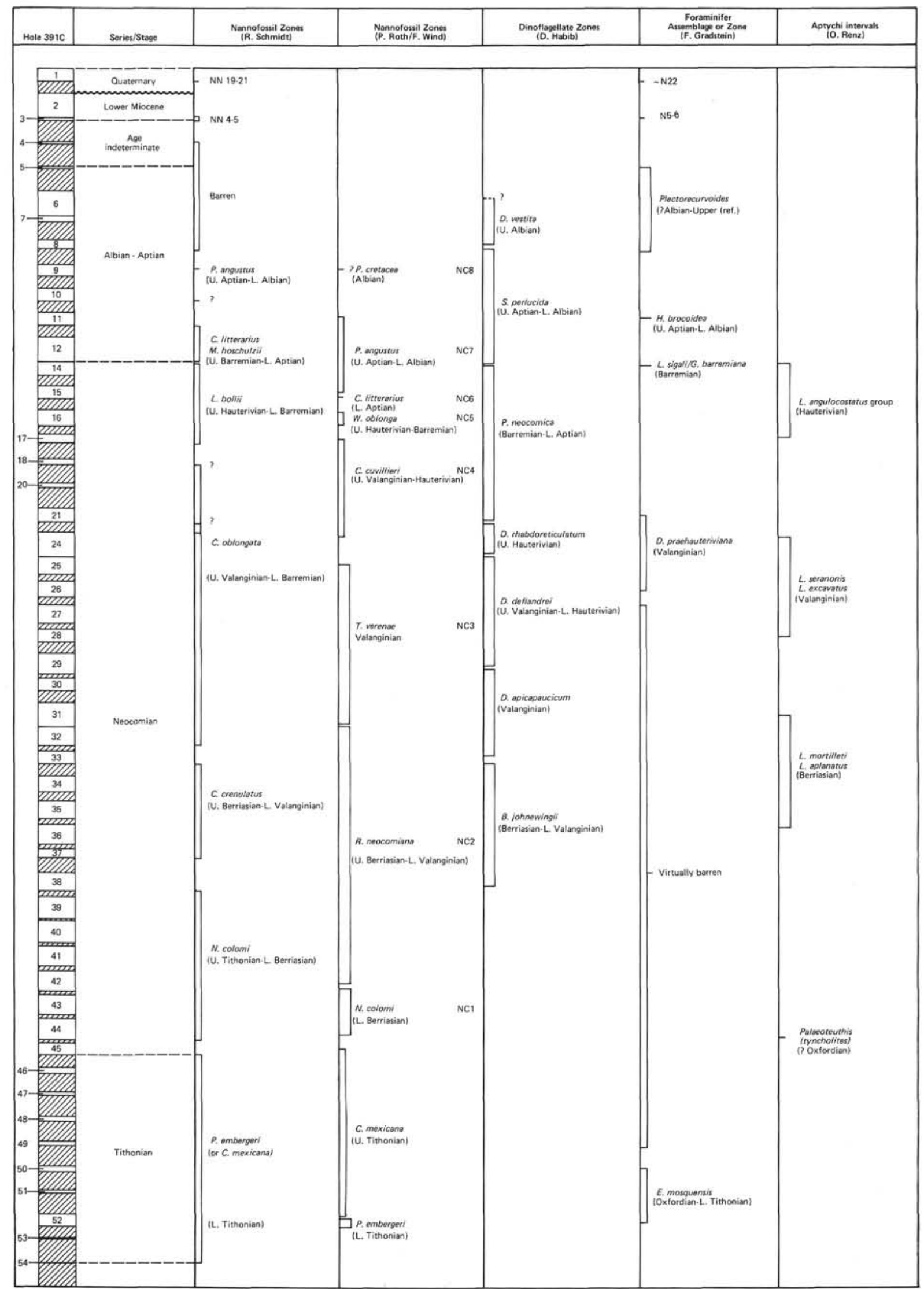

Figure 6. Biostratigraphy of sediments from Hole 391C, Blake-Bahama Basin. 